Australian Journal of

Crop Science

\title{
Evaluation of different soilless media on growth, quality, and yield of cucumber (Cucumis sativus L.) grown under greenhouse conditions
}

\author{
Ahmad M. Al-Far*, Maher J. Tadros, Ibrahim M. Makhadmeh \\ Jordan University of Science and Technology (JUST), Faculty of Agriculture, Jordan \\ *Corresponding author: amalfar16@agr.just.edu.jo
}

\begin{abstract}
This experiment was conducted during spring growing season of 2018 at Jordan University of Science and Technology (JUST) campus in northern Jordan $32.4950^{\circ} \mathrm{N}, 35.9912^{\circ} \mathrm{E}$. The aim of the study was to evaluate the effect of different soilless media such as T: Tuff $100 \%$; TP: Tuff + Perlite 50\% each; TPS: Tuff + Perlite + Sawdust 33\% each; and TS: Tuff + Sawdust 50\% each on some of morphological, physiological and biochemical characteristics related to the quality and quantity of seedless and baby cucumber cultivars. The experimental design was split plot with factorial arrangements and four replications. The measurements related to plant morphology: height, shoot and root length, shoot root fresh and dry weight, number of leaves and flowers, fruit quality: total yield, weight, diameter, hardness, length and numbers per plant. Fruit total soluble solids, the potential of hydrogen $\mathrm{pH}$ and electrical conductivity EC of fruit juice, leaf chlorophyll content, leaf relative water content and fruit water content, fruit and shoot biochemical content minerals, organic matters, fats, fibers, and proteins were also measured. The results indicated significant differences in both cucumber cultivars with respect to all parameters studied. Finally, this study concluded that using TS media for seedless cultivar is the best successful growing soilless media as well as the cheapest compared to other solid media used. On the other hand, using TP media for baby cultivar was the superior growing soilless media that was not expensive compared to other universal media. In addition, the TPS media showed minimum growth and low yield in both cucumber cultivars.
\end{abstract}

Keywords: Hydroponics; Cucumis sativus L.; Physicochemical properties of substrate.

\section{Introduction}

Cucumber (Cucumis sativus L.), belongs to the Cucurbitaceae family, one of the most important plant families in agriculture, and one of the basic crops in the greenhouse were being grown on a large scale worldwide (Papadopoulos, 1994). It is one of the creeping vegetables with large consumer demand worldwide (Petre et al., 2015). In addition, it is considered one of the vegetable crops widely cultivated in plastic greenhouses in the Mediterranean region, because of its short growing cycle and its high economic value in off-season harvest (Maršić and Jakše, 2010). Cucumbers can be planted directly through seeding or transplanting (Singh et al., 2018). It is a good source of phytonutrients such as flavonoids, lignans, and triterpenes, which have antioxidants, anti-inflammatory anti-cancer benefits as reported by (Onimisi and Ovansa, 2015). The peel and seeds are considered the most nutrient dense parts of the cucumber. In addition, cucumber seeds are a good source of minerals and used in diet and disease treatment programs (Onimisi and Ovansa, 2015). As a rule of thumb, the soil is usually the most available growing medium for plants. It provides anchorage, nutrients, air, water, etc. for successful plant growth and for microorganisms (Sepehri et al., 2018). Since the crops on soil show major problems due to pathogen attacks and soil limiting factors, it is required to conduct soil treatments using either chemical or thermal methods that are not environmentally friendly. Moreover, these methods of disinfection are either too expensive or too polluting to the soil and/or groundwater (Petre et al., 2015). Besides, other problems such as nematodes, unsuitable soil reaction, unfavorable soil compaction, poor drainage, degradation due to erosion, salinity, etc. all reduce yield. In addition, conventional growing crops in soil open field agriculture are somewhat difficult as it involves large space, many workers and a large volume of water (Asaduzzaman et al., 2015). In addition, weed control could not be avoided (Hussain et al., 2014). Soilless or hydroponics culture is one of the modern techniques. They are considered as important technologies for better water use efficiency as well as high good quality and quantity products. Among various soilless culture practices, the use of substrates considered the easiest to adapt by growers. Substrates defined above, solely or mixed 
appropriately, provide better root system conditions, compared to those offered by agricultural soil (Wilkinson et al., 2014). Numbers of organic and inorganic materials such as gravel, sand, peat, sawdust, pumice, tuff, coir, vermiculite, perlite, and rock wool pure or in mixture are used as solid growing media in addition to hydroponics (Water), aeroponics and aquaponics as cropping systems (Johnson et al., 1985; Papadopoulos, 1994; Massa et al., 2011; Hussain et al., 2014 and Putra and Yuliando, 2015). The selection of a particular material as a substrate depends on its availability, cost and local experience on its use (Sahin et al., 2003 and Sorin et al., 2015). Such substrates replace the soil because the natural soils are often poorly suited for cultivation and contain chemical, physical, or biological contaminations (Asaduzzaman et al., 2015). The substrate plays a key role to support the plant, and provides air, water, and nutrients to the roots. In addition, it must not contain pathogens and should not be phototoxic. The aim of this study was to evaluate different soilless solid media with different cucumber cultivars to investigate the suitable growing and inexpensive media for planting cucumber. In addition, to study plant response to the quality and quantity of cucumber yield under greenhouse conditions.

\section{Results}

The different soilless growing media showed a dramatically significant effect on morphological, physiological and biochemical characteristics of both cucumber cultivars such as fruit production and shoot, and root parameters.

\section{Results of physicochemical properties of soilless growing media}

The physicochemical properties of soilless growing media results demonstrated in Table 1 . The Soilless media showed a variation between their physicochemical properties. The media T showed lower WHC, higher $\mathrm{pH}$, high EC, higher $(\rho)$ and lower porosity compared to media TP that has high WHC, high $\mathrm{pH}$, higher EC, high $\rho$ and high porosity. TPS media showed higher WHC, neutral $\mathrm{pH}$, lower EC, lower $\rho$ and higher porosity compared to media TS which showed high WHC, lower $\mathrm{pH}$, low $E C$, high $\rho$ and high porosity.

\section{Cucumber yield}

The results of average fruit diameter $(\mathrm{cm})$, average fruit length $(\mathrm{cm})$, average total fruits number, and average fruits weight $(\mathrm{g})$ per plant presented in Table 2 . The results showed the main effect of soilless media and cucumber cultivars yield. Generally, the media filled with sawdust showed the lowest values compared to other soilless media. On the other hand, the cucumber cultivars are genetically different in fruit parameters, which the soilless media affected the quantity of the fruits. Plate 1 demonstrated the cucumber yield for both cultivars per one plant, when grown in media TP.

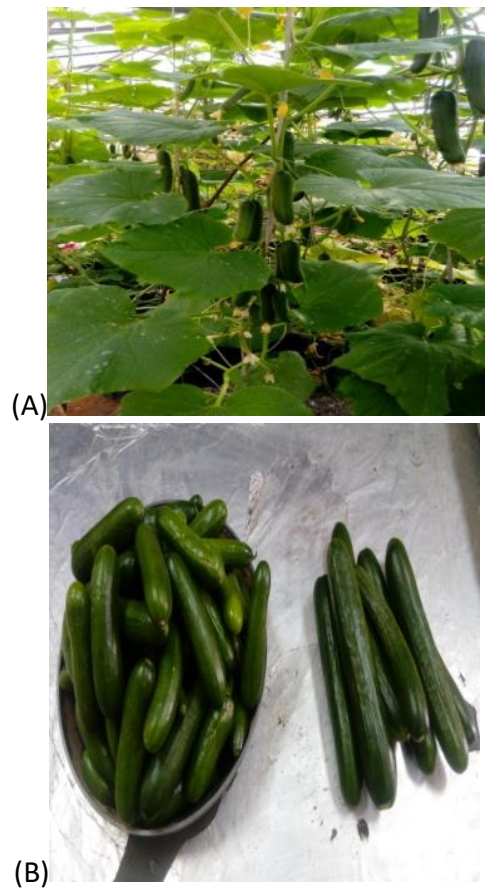

Plate 1. (A) full cucumber growth and (B) demonstrated the cucumber yield for both cultivars per one plant.

\section{Plant height and morphological characteristics of shoot and root}

Shoot and root characteristics presented in Figure 1, where they showed significant differences. The highest plant height was scored for seedless cultivars grown in media TP $(229.5 \mathrm{~cm})$, compared to the lowest value $(204.8 \mathrm{~cm})$ grown in media TS. Shoot fresh weight scored the highest value when grown in media TS (376.7g) compared to the lowest value $265.4 \mathrm{~g}$ in media TP. The shoot dry weight scored the highest value when grown in media T $(52.1 \mathrm{~g})$ compared to the lowest value $40.2 \mathrm{~g}$ in media TPS. The baby cultivar scored the highest value of plant highest when grown in media TPS $(239.3 \mathrm{~cm})$, compared to the lowest value $(204.3 \mathrm{~cm})$ in media TS. Shoot fresh weight scored the highest value when grown in media TP $(401.5 \mathrm{~g})$ compared to the lowest value $(242.9 \mathrm{~g})$ in media TS. Shoot dry weight scored the highest value when grown in media TP $(71.5 \mathrm{~g})$ compared to the lowest value $(27.5 \mathrm{~g})$ in media TPS. Figure 2 represents root characteristics for both cultivars the root length $(A)$, the root fresh weight (B) and root dry weight. The results showed the highest root length for seedless cultivar when grown in media TS $(34.3 \mathrm{~cm})$ compared to the lowest value when grown in media TP $(25.8 \mathrm{~cm})$. The highest root fresh weight $(62.5 \mathrm{~g})$ was observed in media TP compared to lowest value $15.2 \mathrm{~g}$ obtained from media TPS. The highest root dry weight $(8.66 \mathrm{~g})$ in media TP compared to the lowest value $(1.78 \mathrm{~g})$ when grown in media TPS. On the other hand, the baby cultivar scored the highest value of root length $(26.8 \mathrm{~cm})$, when grown in media TP and the lowest value (19.5), when grown in media TS. Root fresh scored the highest value $(82.5 \mathrm{~g})$ in media TP and the lowest $(14.3 \mathrm{~g})$ when grown in 
media TS. Root dry weight scored the highest value $(8.05 \mathrm{~g})$ when grown in media T and lowest $(1.64 \mathrm{~g})$ when grown in media TS.

\section{Stem diameter, leaf and flower numbers}

The stem diameter and flower numbers showed significant differences between both cucumber cultivars in the different soilless media (Figure 3). Generally, the results of the seedless cultivar for stem diameter showed the lowest values $0.90 \mathrm{~cm}$ when grown in media TP and the lowest $0.80 \mathrm{~cm}$ for baby cultivar when grown in media TS. The flower number did not show highly significant between the treatments except for media $T$ that scored the highest number of leaf for the baby cultivar. The number of leaves was not significantly different under the different treatments under our experimental conditions.

\section{Physiological characteristics}

The LRWC and LCC of both cultivars grown in different soilless growing media were satisfactorily presented in Table 3 . The plants grown in LRWC showed higher values than other media but lower LCC. The FWC did not show any significant differences under our experimental conditions.

\section{Fruit hardness, fruit TSS, $\mathrm{pH}$ and EC of fruit juice}

The results showed a significant difference between soilless media types and both cucumber cultivars with respect to fruit hardness and TSS (Figure 4). The results of fruit hardness for seedless cultivar showed the highest value $(4.43 \mathrm{~kg} / \mathrm{f})$ when grown in media TS, while the lowest value observed $(3.26 \mathrm{~kg} / \mathrm{f})$ in media TP, compared to baby cultivar which did not show a significant difference in any of soilless media. The TSS of seedless cultivar scored the highest value (3.48 Brix) when grown in media $\mathrm{T}$ compared to the lowest value (2.70 Brix) that observed in media TP. The baby cultivar scored the highest TSS (2.45 Brix), when grown in media TP and the lowest value (1.40 Brix) in media T. On the other hand, Figure 5 shows that $\mathrm{pH}$ and $\mathrm{EC}$ of fruit juice were significantly different in both cultivars, when grown under different soilless growing media. The results scored the highest values of $\mathrm{pH}$ for seedless cultivar (5.61), when grown in media TS and the lowest value (5.51), when grown in media $\mathrm{TP}$, compared to the highest $\mathrm{pH}$ value for baby cultivar (6.47), when grown in media TS and lowest value (5.38), when grown in TP media. On the other hand, the EC of fruit juice scored the highest value for seedless $(451.3 \mu \mathrm{S} / \mathrm{cm})$, when grown in media TS and the lowest EC value $(247.5 \mu \mathrm{S} / \mathrm{cm})$ in TPS, while the baby cultivar showed the highest EC value $(863.3 \mu \mathrm{S} / \mathrm{cm})$ in TP and lowest value $(356.5 \mu \mathrm{S} / \mathrm{cm})$ in T media.

\section{Fruits biochemistry analysis}

The Total crude fats (\%), total crude proteins (\%), total crude fibers (\%) and organic matters (\%) of fruits were analyzed in both cucumber cultivars. The fat and protein content was represented in Figure 6. The results showed the highest value of fat for seedless cultivar (3.19\%) when grown in T media compared to the lowest value (1.44\%) in media TS. The baby cultivar showed the highest value of fat (2\%) in media TP compared to $1.13 \%$ as the lowest value in media TS. The highest protein value for seedless cultivar (20.19\%) was observed in media T compared to $17.75 \%$ as the lowest value in media TS. The baby cultivar showed the highest protein $(19.33 \%)$ in media TS and the lowest value $(17.53 \%)$ in media T. Soilless media did not significantly affect the organic matter result, while the fiber results increased with media filled by sawdust (Table 4). In addition, the fruit minerals did not show a significant difference across soilless media except for the nitrogen content (Figure 6), where the highest value (3.230\%) was observed in media T for seedless and lowest $2.805 \%$ for baby cultivar, compared to the highest value $3.092 \%$ of baby in media TS and lowest $2.841 \%$ for seedless cultivar.

\section{Shoot biochemistry analysis}

On the other hand, the shoot minerals nitrogen ( $\mathrm{N} \%$ ), phosphorus ( $\mathrm{P} \mu \mathrm{g} / \mathrm{g}$ ), potassium ( $\mathrm{K} \mu \mathrm{g} / \mathrm{g}$ ), sodium ( $\mathrm{Na} \mu \mathrm{g} / \mathrm{g}$ ), magnesium ( $\mathrm{Mg} \mu \mathrm{g} / \mathrm{g}$ ) and calcium (Ca $\mu \mathrm{g} / \mathrm{g}$ ) was significantly different between media in both cucumber cultivars (Figure 7). Generally, the results of $\mathrm{N}$ and $\mathrm{K}$ contents were highest, when both cultivars were grown in sawdust. The $\mathrm{P}$ content scored the highest value in perlite compared to $\mathrm{Na}$ content which scored the highest value in tuff media. The $\mathrm{Mg}$ content for seedless cultivar scored the highest value when grown in sawdust compared to baby cultivar which scored the highest value of $\mathrm{Mg}$ in tuff. The Ca content scored the highest values in both cultivars when grown in media TP and the lowest values in media TS. On the other hand, the shoot organic matters (OM \%), crude fats (\%), crude proteins (\%), and crude fibers (\%) (Figure 8) showed significant differences between all treatments. The results demonstrated that OM \% for both cultivars scored the highest values $\approx 76 \%$ when grown in media TS and lowest values $66.96 \%$ for seedless and $73.63 \%$ for baby in media T. The fat content (\%) scored highest values $2.82 \%$ for seedless and $2.72 \%$ for baby cultivar in T media. The lowest value of $1.43 \%$ was observed for seedless and $0.42 \%$ for baby values in TP media. The highest protein content (18.46\%) was observed for seedless cultivar in media TP and the lowest for baby cultivar $15.18 \%$, while the highest protein content (18.58\%) was recorded for baby cultivar in TS media and the lowest for seedless cultivar (15.11\%). The fiber (\%) scored the highest values (25.01\%) for seedless and $28.60 \%$ for baby in TP media. The lowest value was observed for seedless cultivar (12.63\%) grown in media TPS and for baby (15.74\%) in TS media.

\section{Discussion}

This study showed and documented the effectiveness of soilless cultivation on the different cucumber cultivars grown in different growing soilless media. The results showed significant differences for both cucumber cultivars across different soilless media. The differences in physicochemical properties of soilless media are shown in Table 1 . The differences between the cultivars interact with environments mainly due to the genetic potential and/or the properties of substrates and their mixture ratio with raw materials. 
Table 1. Some physicochemical properties of soilless growing media.

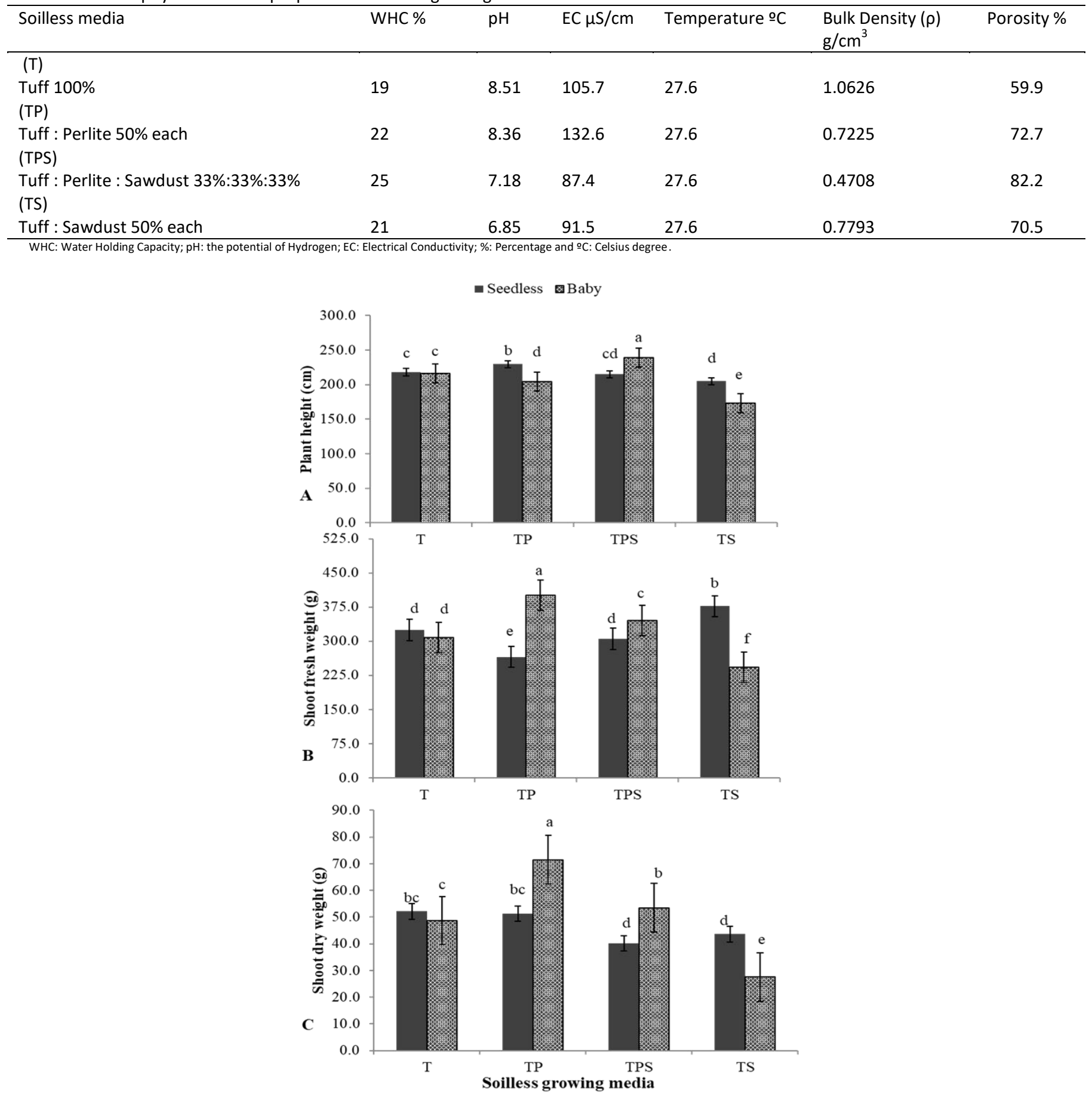

Fig 1. Effect of different soilless growing media on plant height (A), shoot fresh weight (B) and shoot dry weight (C) for both cultivars. Columns with similar letters are not significantly different at $P \leq 0.05$ (LSD: plant height $=6.20$, shoot fresh weight $=20.9$ and shoot dry weight= 4.23). Where; T: Tuff 100\%, TP: Tuff: Perlite 50\% each, TPS: Tuff: Perlite: Sawdust 33\% each and TS: Tuff: Sawdust 50\% each. 
Table 2. Effect of different soilless growing media on cucumber yields for both cultivars.

\begin{tabular}{|c|c|c|c|c|}
\hline \multicolumn{5}{|c|}{ Soilless media } \\
\hline Soilless Media & $\begin{array}{l}\text { Average fruit length } \\
(\mathrm{cm})\end{array}$ & Average total fruit number & Average total fruit weight (g) & $\begin{array}{l}\text { Average fruit diameter } \\
(\mathrm{cm})\end{array}$ \\
\hline$(\mathrm{T})$ & $11.42^{\mathrm{a}}$ & $40.87^{\mathrm{a}}$ & $1904.3^{\mathrm{a}}$ & 2.01 \\
\hline (TP) & $10.90^{\mathrm{a}}$ & $41.25^{\mathrm{a}}$ & $1971.1^{\mathrm{a}}$ & 2.05 \\
\hline (TPS) & $8.90^{\mathrm{b}}$ & $31.50^{b}$ & $1153.1^{\mathrm{b}}$ & 1.53 \\
\hline (TS) & $8.65^{b}$ & $31.50^{b}$ & $1298.2^{\mathrm{b}}$ & 1.58 \\
\hline LSD & 1.14 & 7.14 & 343.5 & NS \\
\hline \multicolumn{5}{|c|}{ Cucumber cultivars } \\
\hline Cultivars & $\begin{array}{l}\text { Average fruit length } \\
(\mathrm{cm})\end{array}$ & Average total fruit number & Average total fruit weight (g) & $\begin{array}{l}\text { Average fruit diameter } \\
(\mathrm{cm})\end{array}$ \\
\hline Seedless & $12.29^{\mathrm{a}}$ & $24.12^{b}$ & 1644.3 & 1.99 \\
\hline Baby & $7.64^{b}$ & $48.43^{\mathrm{a}}$ & 1519.0 & 1.59 \\
\hline LSD & 2.44 & 12.29 & NS & NS \\
\hline
\end{tabular}
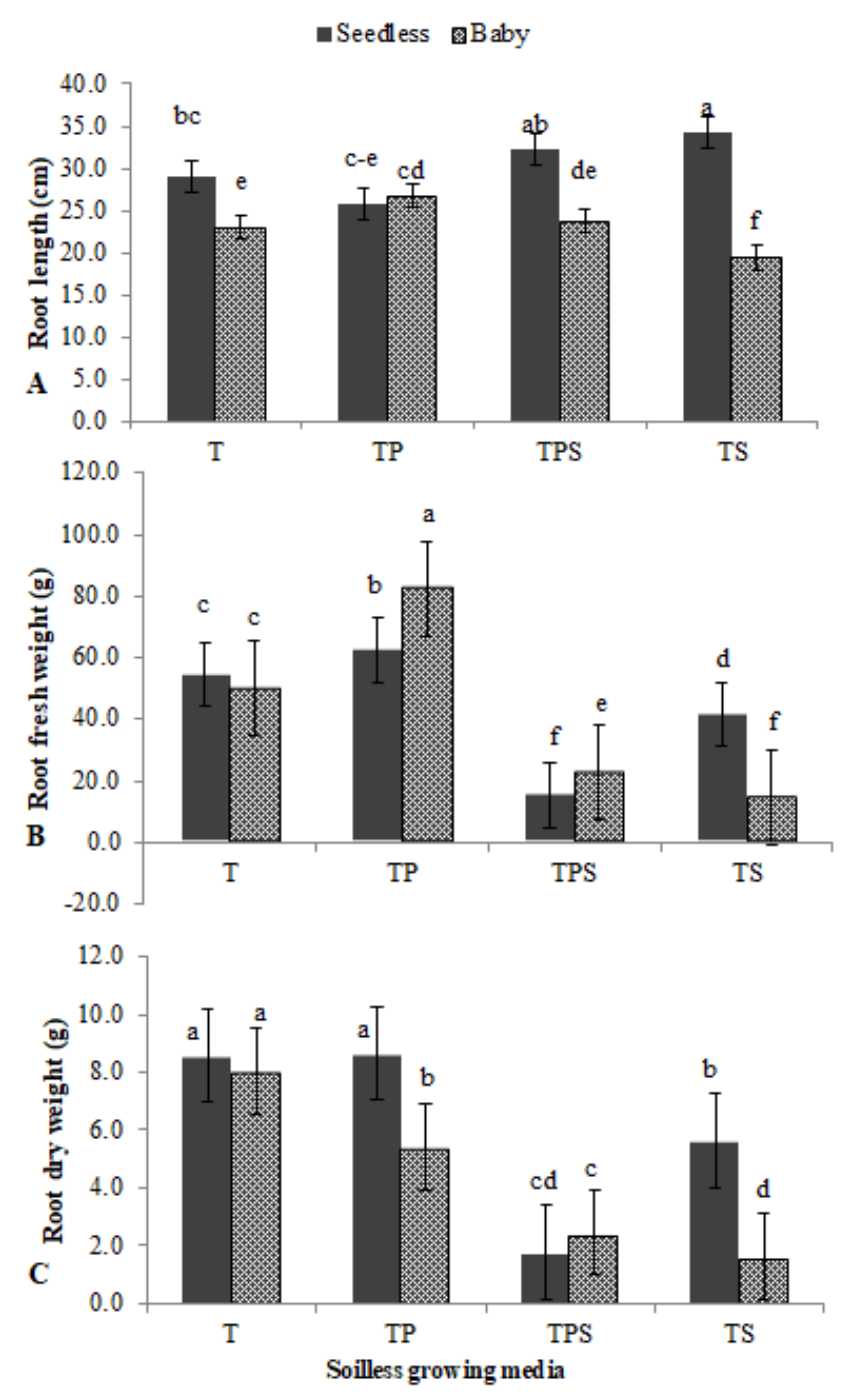

Fig 2. Effect of different soilless growing media on root length (A), root fresh weight (B) and root dry weight (C) on both cultivars. Columns with similar letters are not significantly different at $P \leq 0.05$ (LSD: root length $=3.4$, root fresh weight= 5.7 and root dry weight= 0.81). Where; T: Tuff 100\%, TP: Tuff: Perlite 50\% each, TPS: Tuff: Perlite: Sawdust 33\% each and TS: Tuff: Sawdust $50 \%$ each. 
Table 3. Effect of LRWC and LCC of both cucumber cultivars when grown in different soilless growing media.

\begin{tabular}{lll}
\hline Soilless Media & LRWC (\%) & LCC $\left(\mathrm{mg} / \mathrm{m}^{2}\right)$ \\
\hline M1 (T) & $66.77^{\mathrm{b}}$ & $200.25^{\mathrm{a}}$ \\
M2 (TP) & $63.98^{\mathrm{b}}$ & $196.38^{\mathrm{a}}$ \\
M3 (TPS) & $78.60^{\mathrm{a}}$ & $169.88^{\mathrm{ab}}$ \\
M4 (TS) & $74.47^{\mathrm{a}}$ & $148.38^{\mathrm{b}}$ \\
LSD & 7.59 & 33.30
\end{tabular}

Values with similar letters are not significantly different at P $\leq 0.05$. Were T: Tuff $100 \%$, TP: Tuff: Perlite $50 \%$ each, TPS: Tuff: Perlite: Sawdust $33 \%$ each and TS: Tuff: Sawdust $50 \%$ each. Where the LRWC: Leaf Relative Water Content and LCC: Leaf Chlorophyll Content.
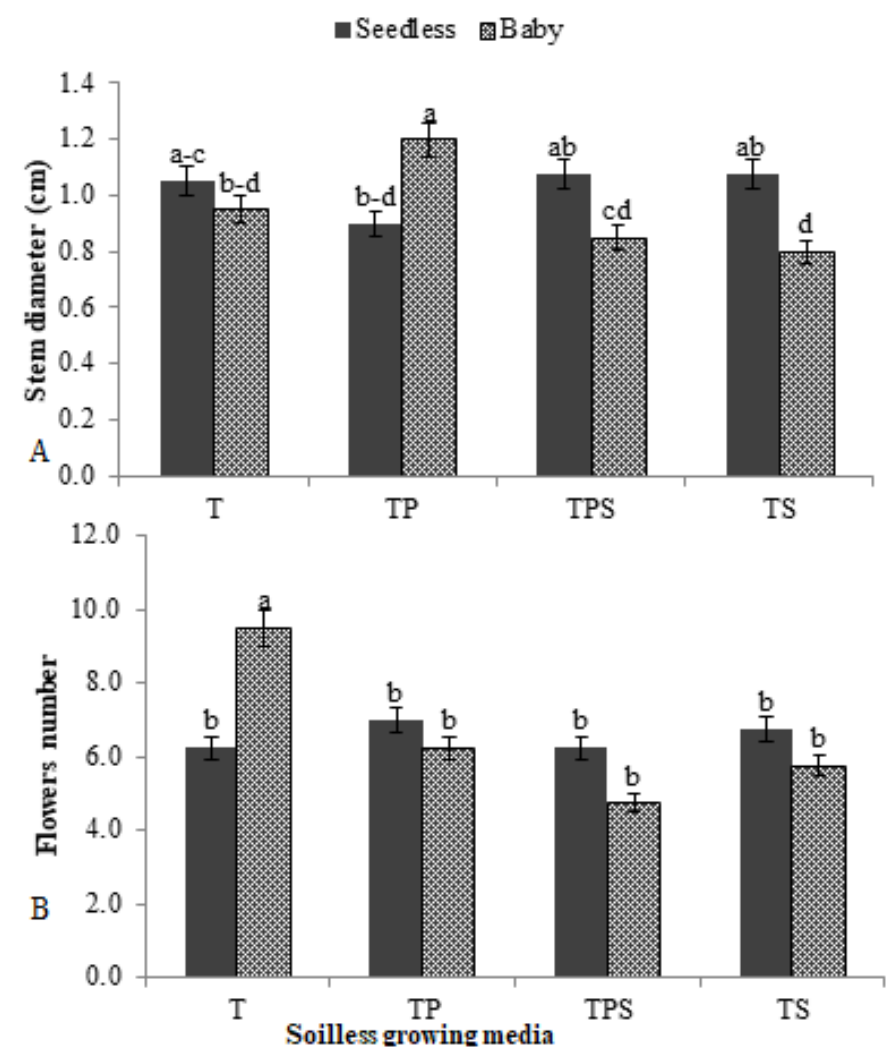

Fig 3. Effect of different soilless growing media on stem diameter (A) and flower numbers (B) of both cultivars. Columns with similar letters are not significantly different at $\mathrm{P} \leq 0.05$ (LSD: stem diameter=0.23 and flower numbers $=2.47$ ). Where; T: Tuff $100 \%, T P$ : Tuff: Perlite 50\% each, TPS: Tuff: Perlite: Sawdust 33\% each and TS: Tuff: Sawdust 50\% each.

Table 4. Effect of fruit organic matter content and crude fiber content on cucumber cultivars when grown in different soilless growing media.

\begin{tabular}{lll}
\hline Soilless Media & Organic matter (\%) & Fiber \% \\
\hline (T) & $91.26^{\mathrm{a}}$ & $5.34^{\mathrm{b}}$ \\
(TP) & $90.39^{\mathrm{a}}$ & $5.56^{\mathrm{b}}$ \\
(TPS) & $90.29^{\mathrm{a}}$ & $6.20^{\mathrm{a}}$ \\
(TS) & $89.02^{\mathrm{b}}$ & $6.25^{\mathrm{a}}$ \\
LSD & 1.18 & 0.52 \\
\hline
\end{tabular}



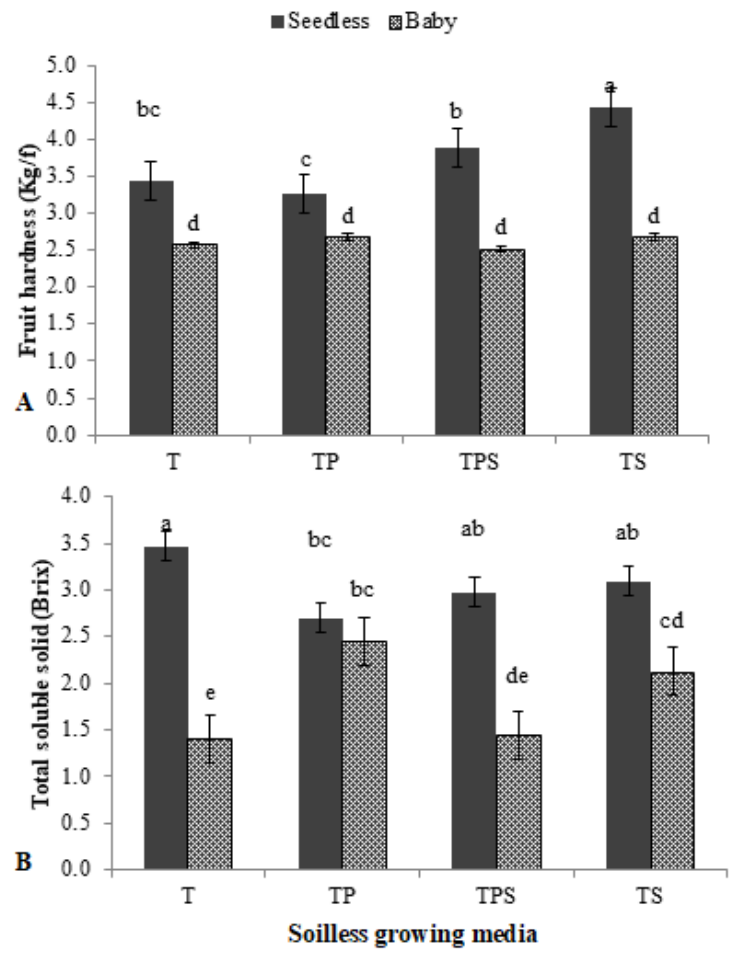

Fig 4. Effect of different soilless growing media on fruit hardness (A) and fruit total soluble solid TSS (B) on both cultivars. Columns with similar letters are not significantly different at P $\leq 0.05$ (LSD: fruit hardness $=0.47$ and TSS $=0.69$ ). Where T: Tuff $100 \%$, TP: Tuff: Perlite $50 \%$ each, TPS: Tuff: Perlite: Sawdust 33\% each and TS: Tuff: Sawdust 50\% each.

QSeedless 중 Baby
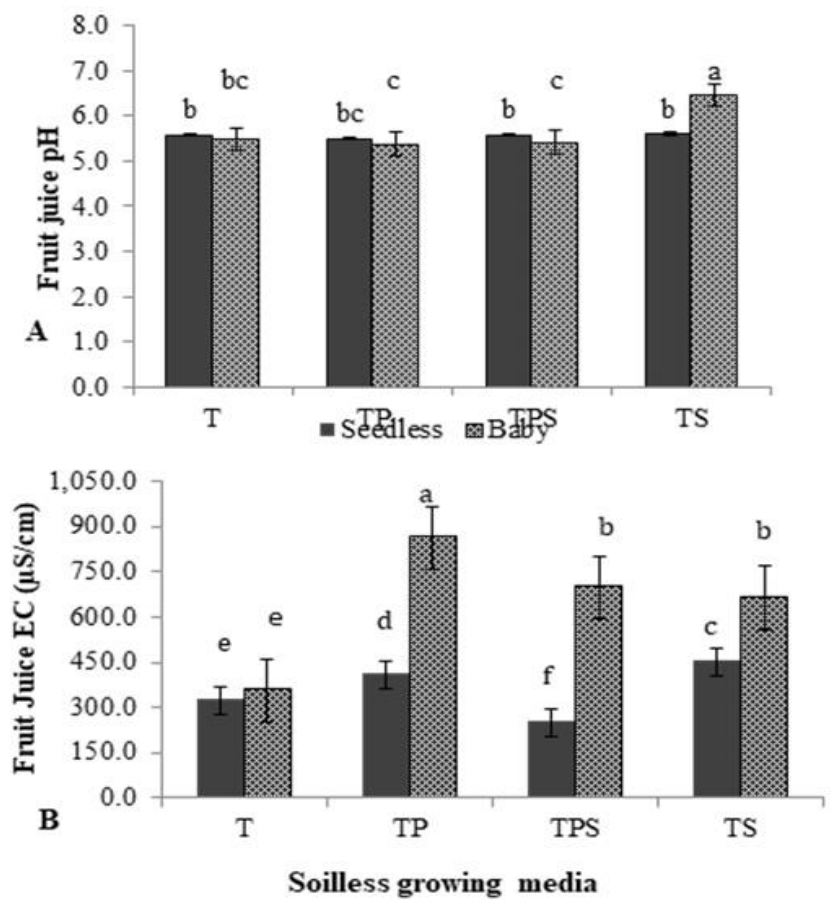

Fig 5. Effect of different soilless growing media on $\mathrm{pH}(\mathrm{A})$ and $\mathrm{EC}(\mathrm{B})$ of fruit juice in both cultivars. Columns with similar letters are not significantly different at $\mathrm{P} \leq 0.05$ (LSD: $\mathrm{pH}_{\mathrm{A}}=0.15, \mathrm{EC}_{\mathrm{A}}=41.5$ ). Where; T: Tuff 100\%, TP: Tuff: Perlite 50\% each, TPS: Tuff: Perlite: Sawdust 33\% each and TS: Tuff: Sawdust 50\% each. 

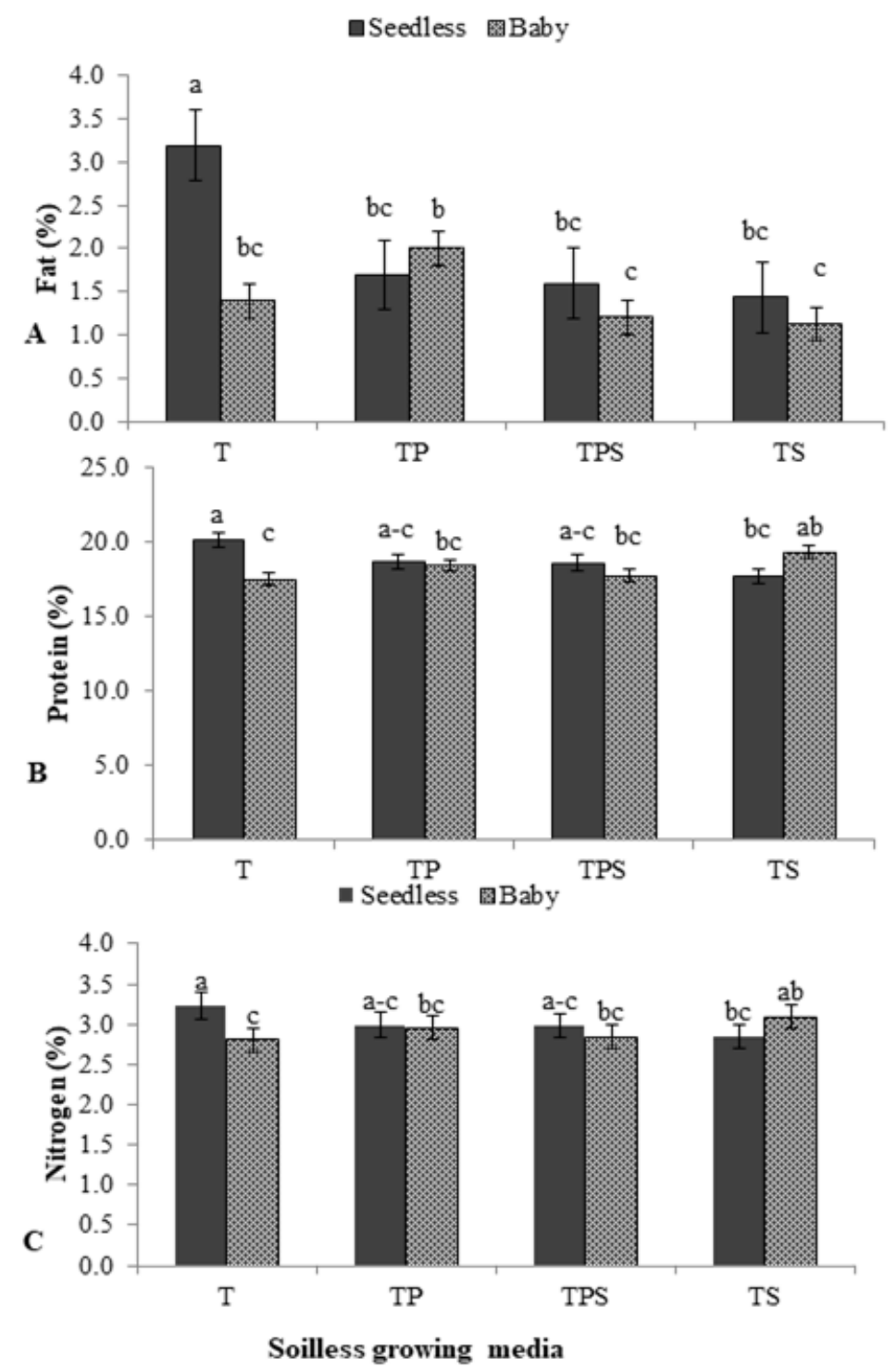

Fig 6. Effect of different soilless growing media on fruit fat (A), fruit protein (B) and fruit nitrogen (C) contents of cultivars. Columns with similar letters are not significantly different at $P \leq 0.05$ (LSD: fruit fat content $=0.67$, fruit protein content $=1.68$ and nitrogen content= 0.269). Where T: Tuff 100\%, TP: Tuff: Perlite 50\% each, TPS: Tuff: Perlite: Sawdust 33\% each and TS: Tuff: Sawdust 50\% each.

In addition, the soilless media showed differences in physicochemical properties. All of these properties could affect plant growth, yields and quality. In addition, the most important properties in soilless cultivation such as $\mathrm{pH}$ and $\mathrm{EC}$ reflected the nutrients availability and competition to absorbance. However, previous short-term studies did not focus on the soilless media ratio or the parameters that were measured here, where we evaluated the different soilless media with respect to cucumber production, quality and quantity.

The tuff has natural strong sorption properties, like high cation exchange capacity (CEC) and macro and micronutrient content like high sodium that make it an attractive alternative media (Manolov et al., 2006; Baudoin et al., 2013 and Eghtedary et al.,
2016). Each tuff deposit has unique chemical composition, physical and mechanical properties for their successful application in agriculture (Baudoin et al., 2013). Tuff also shows the $\mathrm{pH}$ stability in media because it has buffering properties and it also causes the stability of organic matter in media (Manolov et al., 2006 and Eghtedary et al., 2016). Tuff possess a buffering capacity and absorb or release nutrients, especially phosphorus, during the growth period (Raviv et al., 2008).

In addition, it can absorb extensive extra cations from media and even from irrigation water, which will lead to a balance between macronutrient cations (Savvas et al., 2004 and Eghtedary et al., 2016). 

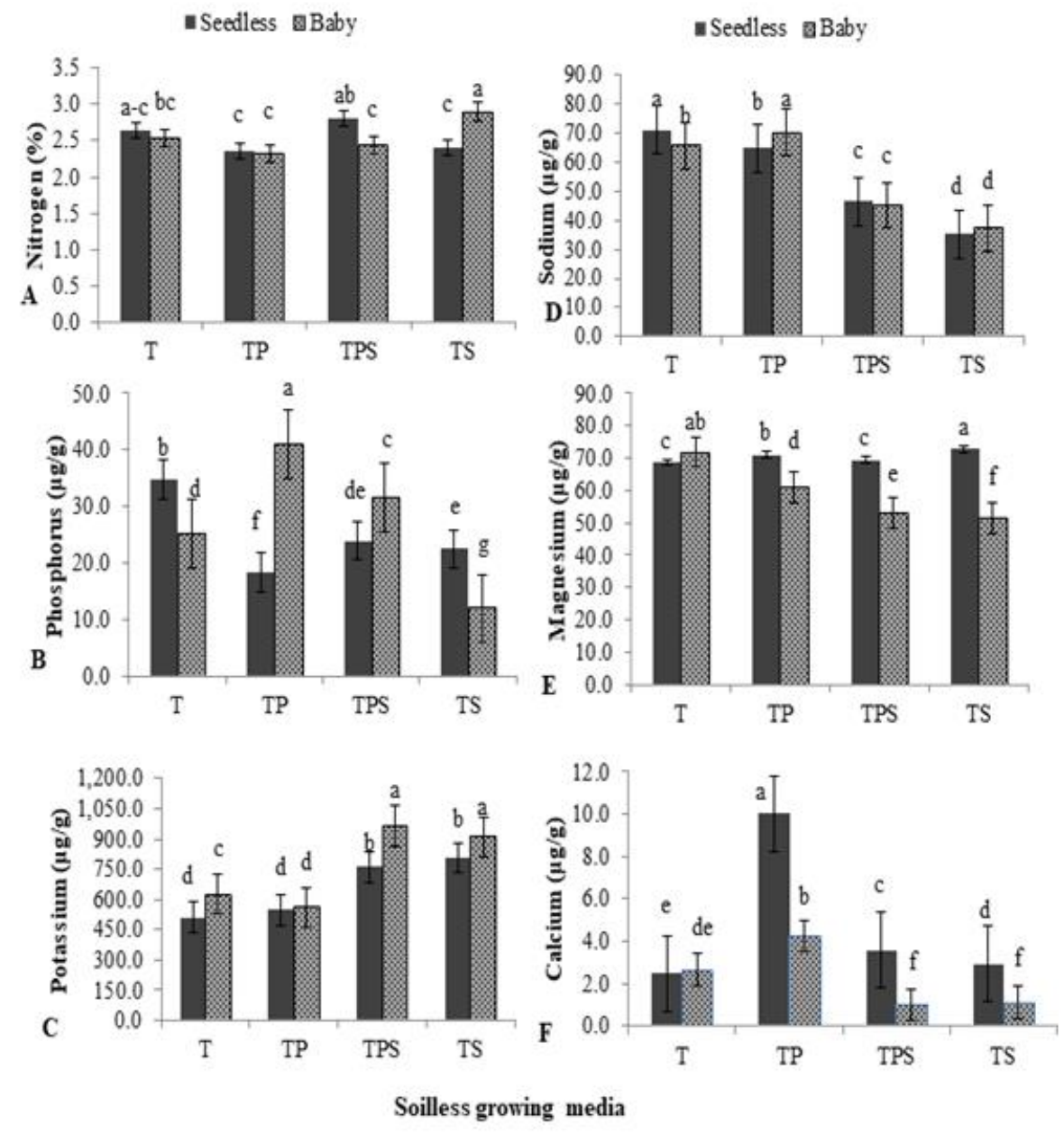

Fig 7. Effect of different soilless growing media on Nitrogen $N(A)$, phosphorus $P(B)$, potassium $K(C)$, sodium $N a(D)$, magnesium $M g$ (E) and calcium $\mathrm{Ca}(\mathrm{F})$ of cultivars. Columns with similar letters are not significantly different at $\mathrm{P} \leq 0.05$. (LSD: $N=0.36, P=1.85, K=57.4$, $\mathrm{Na}=2.29, \mathrm{Mg}=1.45$ and $\mathrm{Ca}=0.39)$. Where T: Tuff 100\%, TP: Tuff: Perlite 50\% each, TPS: Tuff: Perlite: Sawdust 33\% each and TS: Tuff: Sawdust $50 \%$ each.

The perlite shows improved aeration, drainage, optimum moisture retention, nutrient availability and produce a lightweight material with high porosity (Papadopoulos, 1994 and Baudoin et al., 2013). In addition, it is infertile and has a minimal CEC, with neutral pH (Wilkinson et al., 2014 and Hussain et al., 2014). The sawdust shows physical properties such as biodegradability at an acceptable rate, low superficial specific gravity, high porosity, high water retention, moderate drainage, and high bacterial tolerance, elevated the usage of sawdust as a plant growth medium in manufacturing industries (Maharani et al., 2010). In addition, it has specifically been chosen as a test material because it is the most commonly used and readily available worldwide (Maharani et al., 2010 and Baudoin et al., 2013). The sawdust should be horticulturalgrade sawdust and should be free from contaminants that are toxic to plants (e.g., antifungal chemicals used by the lumber industry) (Papadopoulos 1994). We only applied sawdust sourced from sawmills because other wood residues, such as treated boards, may contain preservatives or harmful chemicals and can contain high levels of salts and other toxic compounds which negatively reflect the suitable growth of plants containing sawdust (Wilkinson et al., 2014). Unfortunately, there is lack of literature and less attention to application of soilless media mixture. To the best of our knowledge, this is the first study to investigate the effectiveness of soilless media for cultivation of cucumber cultivars and their effects on yield quantity and fruit quality. In 2006 Gómez-López et al., used perlite and Nutrient Film Technique (NFT) in the spring season. They reported fruit weight of $340 \mathrm{~g}$ per plant and the fruit length of $160 \mathrm{~mm}$, fruit juice $\mathrm{pH} 5.6$ and fruit hardness $56 \mathrm{~N}-$ Newton- when grown in perlite. 

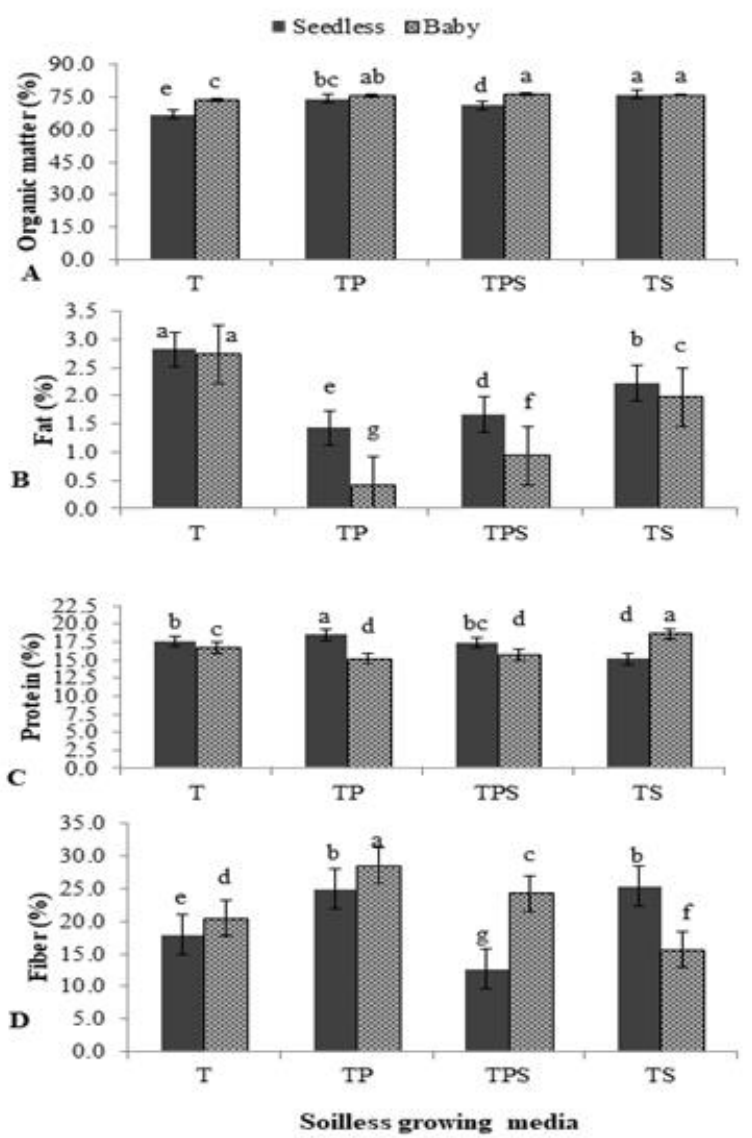

Fig 8. Effect of different soilless growing media on shoot organic matter (A), shoot fat (B), protein (C) and fiber (D) contents for both cultivars. Columns with similar letters were not significantly different at $P \leq 0.05$ (LSD: $O M=1.52$, fat content $=0.12$, protein content $=$ 0.72 and fiber $=0.48)$. Where; T: Tuff 100\%, TP: Tuff: Perlite 50\% each, TPS: Tuff: Perlite: Sawdust 33\% each and TS: Tuff: Sawdust 50\% each.

Application of NFT produced fruit weight of $350 \mathrm{~g}$ per plant. The fruit length was $165 \mathrm{~mm}$, fruit juice $\mathrm{pH} 5.7$ and fruit hardness $55 \mathrm{~N}$, and confirmed less media costs in our study. Yılmaz et al. (2014) studied plant height of seedling grown in tuff $100 \%$. They reporting that seedling height was $4.96 \mathrm{~cm}$ with fresh weight of $0.94 \mathrm{~g}$. This is a results close to our experiment, but the media cost was much lower in our study. Mazahreh et al. (2015) studied perlite as growing media and reported a total yield of 112.1 tons per hectare. They also mixed it with $50 \%$ coconut fiber and reached the yield of 112.9 tons per hectare, while 2:1 perlite and coconut produced a yield of 98.4 ton per hectare. These media were too expensive compared to our used media as well. Maršić and Jakše (2010) reported a root length $41.2 \mathrm{~cm}$ applying perlite, whereas clay pellets produced a root length of $36.6 \mathrm{~cm}$. These values were close to our results in media TS for seedless cultivar $(34.3 \mathrm{~cm})$ and media TPS for baby cultivar $(23.8 \mathrm{~cm})$. In addition, they used effect of perlite on the root fresh weight $(53.8 \mathrm{~g})$ compared to clay pellets $(33.4 \mathrm{~g})$. However, Peyvast et al. (2009), used peat growing media and reported plant fresh weight of $0.45 \mathrm{~kg}$, and stem diameter of $0.98 \mathrm{~cm}$. They also used perlite and showed the stem diameter of $1.01 \mathrm{~cm}$, which supports results of our experiment. The fruit length was $15.62 \mathrm{~cm}$ and the diameter was $27.56 \mathrm{~cm}$, while in sole perlite the fruit length was $15.4 \mathrm{~cm}$ and diameter $28.1 \mathrm{~cm}$. These results are completely different from our results in fruit length and diameter. Using peat alone or perlite the yields of cucumber was $9.78 \mathrm{~kg} \mathrm{~m}^{-2}$ and $8.57 \mathrm{~kg} \mathrm{~m}^{-2}$, respectively. The peat produced TSS of 3.6 (Brix), while in perlite the TSS was (3.5) Brix.

The results in Table 2 and 3 were compared to Petre et al. (2015) where they used perlite and jiffy (peat) in 50-50\% ratio. They showed a variation of $140 \mathrm{mg} / 100 \mathrm{~g}$ vegetal in chlorophyll content. The yields per plant was $14.614 \mathrm{~kg}$ and per area were $26.305 \mathrm{~kg} / \mathrm{m}^{2}$. In addition, the fruits protein content 
was $350 \mathrm{mg} / 100 \mathrm{~g}$ of plant. Cardarelli et al. (2012) reported the fruit mineral contents using coconut, perlite, rockwool and pumice and reported a contrary results to those obtained in our study (Figures $6-\mathrm{C}$ and 7 ). They reported no significant effect of minerals on plant. The mineral contents in leaves were $\mathrm{N}$ 29.7, P 5.7, K 36.7, Ca 32.4 and $\mathrm{Mg} 8.7\left(\mathrm{~g} \mathrm{~kg}^{-1}\right.$ of dry weight) using coconut, while application of perlite showed that ( $\mathrm{N} 31.8, \mathrm{P} 4.2, \mathrm{~K} 36.3$, Ca 36.4 and $\mathrm{Mg} 6.9 \mathrm{~g}$ ). In addition, application of pumice produced minerals as $\mathrm{N} \mathrm{30.3,} \mathrm{P} \mathrm{5.6,} \mathrm{K}$ 36.7, Ca 36.8 and $\mathrm{Mg}$ 7.1), while in rockwool $\mathrm{N}$ 28.2, P 4.4, $\mathrm{K}$ 34.8, Ca 30.2 and Mg 5.7 were detected.

On the other hand, baby cucumber was grown in sawdust. Maboko et al. (2017) reported that application of $100 \%$ nutrients solution produced average plant dry weight of 80.8 $\mathrm{g} /$ plant. The average number of leaves after 70 days was 31.3 while, the results of this research showed fewer leaf numbers due to different treatments and measuring time compared to our experiment. Maboko et al. (2017) reported the leaf chlorophyll content of $43.8 \%$ after 70 days of direct seeding using Single-Photon Avalanche Diode SPAD 502 chlorophyll meter (Konica Minolta, Osaka, Japan). In addition, the marketable fruits per plant were $36.42 \mathrm{~g} /$ plant and marketable yields were $5,498 \mathrm{~g} /$ plant. The TSS for fruit juice was $3.0 \%$ and the $\mathrm{pH}$ and EC for fruit juice were 5.2 and $3.7 \mathrm{~ms} \cdot \mathrm{cm}^{-1}$ respectively, with fewer media costs. In addition, the leaf mineral analysis results showed that $\mathrm{N}, \mathrm{K}, \mathrm{P}, \mathrm{Ca}$ and $\mathrm{Mg}$ were $5.7,3.0,0.58,1.69$, and $0.5 \%$, respectively.

Please start the sentence "Generally, there is less attention for baby cucumber cultivar, according to Shawed and Cantliffe (2003) reported many significant differences in fruit quality between thirteen different cucumber baby cultivars grown in perlite media. The results presented compelling evidence that soilless media are less expensive and available to grow plants worldwide, while they result in higher quantity and quality. Regarding the media's costs-effective, the cheapest was media T, followed by media TS, and media TPS compared to the more expensive media TP. Furthermore, the durability of such media was reduced due to the present of sawdust. The decompositions in media TS was higher than TPS, whereas media T high durability, followed by media TP. Therefore, in the future, care should be taken for biochemical analysis of media to fully understand soilless effects and mode of action in cucumber cultivars especially mini cultivars. It would be interesting to know effect of soilless substrates on other cash crops and recommend their potentials for commercial productions.

\section{Materials and methods}

\section{Physicochemical measurements of soilless solid growing media and cost}

The physicochemical properties of all substrates consisting of bulk density $\rho$ and porosity were measured according to (De Boodt and Verdonck, 1971). The water-holding capacity (WHC), pH and electrical conductivity (EC) were measured carefully according to (Brown and Pokorny, 1975 and Wilkinson et al., 2014) methods. Four different soilless solid media proportions were used (T, TP, TPS and TS) as following:
T: Tuff 100\%, TP: Tuff: Perlite, 50\% for each, TPS: Tuff: Perlite: Sawdust, 33\%: 33\%: 33\% for each and TS: Tuff: Sawdust, 50\% for each volume per volume (V/V). Soilless media cost without taxes and transports were T: US $\$ 35.5$ per Ton; TP: US $\$ 7.5$ per 100 liters; TPS: US \$6 per 100 liters and TS: US \$2 per 100 liters.

\section{Seedling production and growth}

Common cucumber seeds variety Banan F1 (Nunhems) as seedless and Cengel RZ (RijkZwaan) as baby (mini) cultivars were germinated in a mixture of peat moss $70 \%$ : perlite $30 \%$ $(3: 1 \mathrm{v} / \mathrm{v})$. Both cucumber cultivars were grown in 84 tray cells, irrigated twice daily until seedlings produced and then transplanted into plastic boxes at the three-leaf stage after three weeks of planting seeds. The lateral branches were pruned/removed up to $15 \mathrm{~cm}$ and training systems installed. Plants trained following the high wire steel system with two meters wire inside the greenhouse that damnation was 40 meters length, 11 meters width, and 4 meters height.

\section{Setting up the soilless system and nutrients solution}

Sixteen plastic boxes with the dimensions length $49 \mathrm{~cm}$, width $29 \mathrm{~cm}$ and height $11 \mathrm{~cm}$ were prepared for both cultivars as a closed soilless system. Boxes filled with four homogenous different soilless media as (T): Tuff 100\%, (TP): Tuff: Perlite $50 \%$ each, (TPS): Tuff: Perlite: Sawdust 33\% each and (TS): Tuff: Sawdust $50 \%$ each per volume. The tuff or (Black-Zeolite) had a diameter between 0-0.02 Millimeter $(\mathrm{mm})$. The perlite and sawdust with diameter between 3-5 ( $\mathrm{mm}$ ) were obtained from the local market. Two plants per cultivars were sown in each box. A total of 32 plants were grown in this experiment. Both cucumber cultivars were irrigated using Hoagland nutrients solution (Hoagland and Arnon, 1950) supplied through a pump from an irrigation tank.

\section{Cultural practices}

The irrigation was carried out daily and cucumber was harvested twice a week in the early morning. Pesticide and/or sulfur powder were applied when necessary. The average temperature was $26^{\circ} \mathrm{C}$ during daytime and $16^{\circ} \mathrm{C}$ nighttime. In addition, the average relative humidity was $65 \%$. The water sprayed to reduce the temperature and increase the relative humidity in the greenhouse by cooling panel and fans as a ventilation system. The light intensity was between 95-155 $\mathrm{Wm}^{2}$ (watt per square meter) and the photoperiod was between 10-12 hours. The $\mathrm{pH}$ and EC in nutrients solution were monitored on daily basis carefully since it was a key role for nutrients availability. The average $\mathrm{pH}$ value was 6.3 maintained by using Hydrochloric acid ( $\mathrm{HCL}$, Severn Biotech Ltd, UK). In addition, the EC was within the range of 1500 $3000 \mu \mathrm{S}$ microsiemens.

\section{Data collection}

Some of the morphological, physiological and biochemical characteristics were measured for each cucumber cultivars 
in the greenhouse under different soilless growing media. At the same time, four plants were selected randomly from each replication for all treatments.

\section{Plant morphology and physiology}

Plant length and root were measured by tape meter. Shoot and root fresh and dry weight were also measured at the end of experiments by analytical balance precision 0.001 (Mettler Toledo, USA). The leaf and flower number were counted. Fruit quality: total fruits weight, fruit weight by analytical balance (precision 0.001), fruit diameter by caliper (precision 0.01), fruit hardness by FHT-803 device (T-Equipment, USA), fruit length by ruler and numbers per plant were counted and fruit water content (FWC) drying measured according to Ahmed et al., 2013. The shoot, root, and fruit of materials dried in oven (Nabertherm TR 1050, Germany) at $60^{\circ} \mathrm{C}$ for 72 hours.

\section{Plant biochemical analysis}

The total soluble solids (TSS), $\mathrm{pH}$ and EC of fruit juice were measured immediately after harvesting by digital $A B B E$ refractometer (BOECO, Germany) and waterproof meter (HANNA, USA), respectively. The leaf chlorophyll content (LCC) was measured using CCM-300 device (Opti-Sciences, USA), leaf relative water content (LRWC) floating and drying methods were measured as described by (Barrs and Weatherley, 1962). Leaf and fruit minerals content were analyzed using Kjeldahl method, the $P$ by colorimetric analysis using Spectrophotometer device (Mettler Toledo, USA), the $\mathrm{K}$ and $\mathrm{Na}$ by Flame photometry (A.KRÜSS Optronic, Germany), the $\mathrm{Mg}$ and $\mathrm{Ca}$ titration by EDTA method explained by (Estefan et al., 2013). The protein content calculated by multiplying the nitrogen content by constant value 6.25 as described by (Ferguson and Terry, 1954). The organic matter content was determined by the drying method described by (Bremner and Jenkinson, 1960). The fiber content determined as the method described by (Van, 1966) by using ANKOM 2000 Automated Fiber Analyzer device (ANKOM Technology, USA) and the fat content determined as the Ether Extract method described by (Thiex et al., 2003).

\section{Experiment design and statistical analysis}

The layout was split plot in a factorial arrangement with four replications for each treatment. The soilless media were the main plot and cucumber cultivars the subplot. Each replication had four soilless media, two cucumber cultivars and four plants per cultivars. The numbers of observation per treatments were four random plants per cultivars. Data collected from this research were statistically analyzed using the general linear model (GLM) analysis using the statistical software package (SAS version 9.2, 2002). Means separation performed according to the least significant difference (LSD) test at 0.05 probabilities $(\mathrm{P} \leq 0.05)$.

\section{Conclusion}

The increase of population and expansion of arable land are happened due to poor land management and agriculture policies. Climatic and environment changes urge humankind to explore new technologies and cropping systems like soilless culture as a solution for crop production and to supply food demand worldwide. The findings of this research clearly demonstrated that the seedless cucumber cultivar grown in TS substrate showed the best quantity and quality parameters. As a summary the order of soilless cultures were TS > TP, T > TPS. We have also shown that the baby cucumber showed the best parameters when grown in media TP. It showed descending order of TP > T > TS > TPS. The media TPS showed not suitable as a growing media for both cucumber cultivars with respect to growth, yield and quality of cucumbers fruit.

\section{Acknowledgment:}

We would like to thank the Deanship of Scientific Research at JUST University for their financial support to conduct this research under grant number [89/2017]. In addition, a special thank for the Faculty of Agriculture to assistance and conduct this research in their Greenhouse and laboratories.

\section{References}

Ahmed N, Singh J, Chauhan H, Anjum PGA, Kour H (2013) Different drying methods: their applications and recent advances. Int J Food Nutr Safe. 4(1): 34-42.

Asaduzzaman M, Saifullah M, Mollick ASR, Hossain MM, Halim GMA, Asao T (2015) Influence of soilless culture substrate on improvement of yield and produce quality of horticultural crops. In Soilless Culture-Use of Substrates for the Production of Quality Horticultural Crops.

Barrs HD, Weatherley PE (1962) A re-examination of the relative turgidity technique for estimating water deficits in leaves. Aust J Biol Sci. 15(3): 413-428.

Baudoin W, Nono-Womdim R, Lutaladio N, Hodder A, Castilla N, Leonardi C, Duffy R (2013) Principles for Mediterranean climate areas. Good agricultural practices for greenhouse vegetable crops. UN, FAO.

Bremner JM, Jenkinson DS (1960) Determination of organic carbon in soil: I. Oxidation by dichromate of organic matter in soil and plant materials. J Soil Sci. 11(2): 394-402.

Brown EF, Pokorny FA (1975) Physical and chemical properties of media composed of milled pine [Pinustaeda] bark and sand [Ornamental plants]. J Am Soc Hortic Sci. 100:119-121.

Cardarelli M, Rouphael Y, Darwich S, Rea E, Fiorillo A, Colla G (2012) Substrate type affects growth, yield and mineral composition of cucumber and zucchini squash. J Life Sci. 6(7): 766.

DeBoodt MAVO, Verdonck O (1971) The physical properties of the substrates in horticulture. In III Symposium on Peat in Horticulture 26, Ghent, Belgium, pp. 37-44.

Eghtedary-Naeini A, Golabadi M, Hoodaji M (2016) Using enriched zeolite as a slow release iron fertilizer for soilless greenhouse cultivation of cucumber. J PlantNutr. 39(4): 523- 
530.

Estefan G, Sommer R, Ryan J (2013) Methods of soil, plant, and water analysis, third ed. ICARDA . A manual for the West Asia and North Africa region. 170-176.

Ferguson WS, Terry RA (1954) The fractionation of the nonprotein nitrogen of grassland herbage. J Sci Food Agric. 5(11): 515-524.

Gómez-López MD, Fernández-Trujillo JP, Baille A (2006) Cucumber fruit quality at harvest affected by soilless system, crop age and preharvest climatic conditions during two consecutive seasons. Sci Hortic. 110(1):68-78.

Hoagland DR, Arnon DI (1950) The water-culture method for growing plants without soil circular, second ed. California agricultural experiment station USA, 347.

Hussain A, Iqbal K, Aziem S, Mahato P, Negi AK (2014) A review on the science of growing crops without soil (soilless culture)-a novel alternative for growing crops. Int J Agric Crop Sci. 7(11): 833-842.

Johnson H, Hochmuth GJ, Maynard DN (1985) Soilless culture of greenhouse vegetables, Bulletin, Florida Cooperative Extension Service USA.

Maboko MM, Du Plooy CP, Chiloane S (2017) Yield and mineral content of hydroponically grown mini-cucumber (Cucumis sativus L.) as affected by reduced nutrient concentration and foliar fertilizer application. Hort Science. 52(12):1728-1733.

Maharani R, Tamai Y, Takash, Y, Terazawa M (2010) Scrutiny of physical properties of sawdust from tropical countries wood species: effect of different mills and sawdust particle size. J For Res. 7(1):20-32.

Manolov I, Antonov D, Stoilov G, Tsareva I, Baev M (2006) Jordanian zeolitic tuff as a raw material for the preparation of substrates used for plant growth. J Cent Eur Agric. 6(4): 485-494.

Maršić NK, Jakše M (2010) Growth and yield of grafted cucumber (Cucumis sativus L.) on different soilless substrates. J Food Agric Environ. 8(2):654-658.

Massa D, Incrocci L, Maggini R, Bibbiani C, Carmassi G, Malorgio F, Pardossi A (2011) Simulation of crop water and mineral relations in greenhouse soilless culture. Environmental modelling and software. 26(6):711-722.

Mazahreh N, Nejatian A, Mousa M (2015) Effect of different growing medias on cucumber production and water productivity in soilless culture under UAE conditions. Merit Res J Agric Sci Soil Sci. 3:131-138.

Onimisi AO, Ovansa JU (2015) Comparative studies on nutritional values of four varieties of cucumber. International Conference on Latest Trends in Food, Biological and Ecological Sciences (ICLTFBE'15) Dubai UAE pp. 11-12.

Papadopoulos AP (1994) Growing greenhouse seedless cucumbers in soil and in soilless media. Agriculture and AgriFood. Dr. A. P. Papadopoulos Research Centre Harrow, Ontario, Canada.

Petre SN, Pele M, Draghici EM (2015) Influence of perlite and jiffy substrates on cucumber fruit productivity and quality. J Agric Sci. 7(8):185.
Peyvast GH, Olfati JA, Ramezani Kharazi P, Noori Roudsari O (2009) Effect of substrate on greenhouse cucumber production in soilless culture. In IV International Symposium on Cucurbits. Iran, pp. 429-436.

Putra PA, Yuliando H (2015) Soilless culture system to support water use efficiency and product quality: a review. Agric Sci. Procedia. 3:283-288.

Raviv M, Lieth JH, Bar-Tal A, Silber A (2008) Growing plants in soilless culture: operational conclusions. Soilless Culture Theory and Practice. Elsevier Publications, 545-571.

Sahin U, Ercisli S, Anapali O, Esitken A (2003) Regional distribution, some physico-chemical, and physical properties of some substrates used in horticulture in Turkey. In South Pacific Soilless Culture Conference-SPSCC 648, pp. 177-183.

SAS (2002) STAT software, version 9.1. SAS Institute Inc., Cary, NC USA.

Savvas D, Samantouros K, Paralemos D, Vlachakos G, Stamnatakis M, Vassilatos C (2004) Yield and nutrient status in the root environment of tomatoes (lycopersicon esculentum L.) grown on chemically active and inactive inorganic substrates. ActaHortic. 644:377-384.

Sepehri A, Sarrafzadeh MH (2018) Effect of nitrifiers community on fouling mitigation and nitrification efficiency in a membrane bioreactor. Chem Eng Process. 128, 10-18.

Shaw NL, Cantliffe DJ (2003) Hydroponically produced minicucumber with improved powdery mildew resistance. InProc. Fla. State Hort Soc. 116:58-62.

Singh MC, Kachwaya DS, Kalsi K (2018) Soilless cucumber cultivation under protective structures in relation to irrigation coupled fertigation management, economic viability and potential benefits- A Review. Int J Curr Microbiol AppSci. 7(3): 2451-2468.

Sorin P, PELE M, Draghici EM (2015) Study on the influence of substrate culture on the production of cucumbers in unconventional system. Scientific Papers-Series B, Horticulture, Romania, pp. 255-258.

Thiex NJ, Anderson S, Gildemeister B (2003) Crude fat, diethyl ether extraction, in feed, cereal grain, and forage (Randall/Soxtec/submersion method): collaborative study. JAOAC Int. 86(5): 888-898.

Van Soest PJ (1966) Nonnutritive residues: a system of analysis for the replacement of crude fiber. JAOAC Int. 49:546-551.

Wilkinson KM, Landis TD, Haase DL, Daley BF, Dumroese RK (2014) Tropical nursery manual: a guide to starting and operating a nursery for native and traditional plants. Agriculture Handbook 732. Washington, DC: US Department of Agriculture, Forest Service. pp. 100-122.

Yılmaz E, Sönmez i, Demir H (2014) Effects of zeolite on seedling quality and nutrient contents of cucumber plant (Cucumis sativus L. cv. Mostar F1) grown in different mixtures of growing media. Commun Soil Sci Plant Anal. 45(21): 2767-2777. 